Studia nad Autorytaryzmem i Totalitaryzmem 43, nr 2 Wrocław 2021

https://doi.org/10.19195/2300-7249.43.2.23

\author{
TADEUSZ KOCOWSKI \\ ORCID: 0000-0002-4086-8803 \\ Uniwersytet Wrocławski \\ tadeusz.kocowski@uwr.edu.pl
}

\title{
Autorytarne decyzje dyskrecjonalne w procesie nacjonalizacji w Polsce
}

Słowa kluczowe: nacjonalizacja, decyzje administracyjne, decyzje dyskrecjonalne.

\author{
AUTHORITARIAN DISCRETIONARY DECISIONS \\ IN THE PROCESS OF NATIONALIZATION IN POLAND
}

\begin{abstract}
Nationalisation in Poland took place for and without compensation. Decisions concerning the nationalization of German companies, as declaratory decisions confirming only their adoption by law. The remaining enterprises were taken over on the basis of constitutional decisions. These were discretionary decisions to which, due to the effects caused, it was possible to successfully include the term authoritarian.
\end{abstract}

Keywords: nationalisation, administrative decisions, discretionary decisions.

\section{Wstęp}

Zakończenie II wojny światowej związane było ze zmianami politycznymi i gospodarczymi, jakie zaszły w naszym kraju. Ważną rolę odgrywały zmiany dokonywane w sferze stosunków własnościowych, zmierzające w istocie do przejęcia w sferze gospodarki nierolniczej własności podstawowych środków produkcji przez państwo. Warto zaznaczyć, że większość ugrupowań politycznych, także tych znajdujących się na emigracji, w swoich programach przewidywało potrzebę dokonania zmian własnościowych $\mathrm{w}$ gospodarce ${ }^{1}$.

1 S. Grabski, Upaństwowienie czy uspołecznienie i unarodowienie, „Ekonomista Polski” 1942, nr 4, s. 15.

Studia nad Autorytaryzmem i Totalitaryzmem 43, nr 2, 2021

(C) for this edition by CNS 
Prawnego rozstrzygnięcia i uregulowania wymagał problem przejmowanego, opuszczonego mienia poniemieckiego, znajdującego się przede wszystkim na terenie tak zwanych ziem odzyskanych, których przynależność do państwa polskiego długo pozostawała bez jednoznacznego rozstrzygnięcia podjętego przez zwycięskie mocarstwa. Pozbawienia właścicieli majątku produkcyjnego faktycznego władztwa nad nim dokonane zostało w niedługim czasie po wkroczeniu na terytorium państwa polskiego niemieckich wojsk okupacyjnych, a po zakończeniu działań wojennych większość zakładów przemysłowych faktycznie przejmowana była przez nowe władze.

Formalnie nacjonalizacja dokonana została przepisami ustawy z dnia 3 stycznia 1946 roku o przejęciu na własność państwa podstawowych gałęzi gospodarki narodowej ${ }^{2}$, której art. 1 wskazywał cele zamierzone przez prawodawcę. Dokonywana była celem planowego odbudowania gospodarki narodowej, zapewnienia państwu suwerenności gospodarczej i podniesienia ogólnego dobrobytu. Zakres i zasady dokonywanego upaństwowienia przesądzały w istocie o ustanowieniu czynnego udziału państwa w gospodarce na skalę dotychczas w Polsce niespotykaną. Zamiarem państwa było bowiem przejecie na siebie procesów organizowania i prowadzenia gospodarki narodowej ${ }^{3}$.

Organy ówczesnego państwa zostały zaangażowane w realizację zmian w stosunkach własnościowych, pozwalających na wprowadzenie nowego, niewynikającego z celów nacjonalizacji ustroju gospodarczego. Pozostaje wiec ustalić, na ile proces stanowienia prawa nacjonalizacyjnego - a przede wszystkim praktyka jego stosowania, czyli wydawania odpowiednich decyzji - sprzyjał realizacji celu. Szczególnie warto ustalić, czy i na ile działania mające na celu stosowanie prawa nacjonalizacyjnego dokonywane były z maksymalnym wykorzystaniem możliwości prawnych tworzonych specjalnie w procesie stanowienia prawa, doprowadzając do rażącego jego naruszana w procesie stosowania.

\section{Otoczenie prawne nacjonalizacji}

Działaniom nacjonalizacyjnym podjętym po II wojnie światowej sprzyjała także sytuacja faktyczna, w jakiej znalazł się prywatny majątek produkcyjny, wynikająca zarówno z działań wojennych, jak i regulacji prawnych okresów przedwojennego, wojennego oraz tych wprowadzonych przez okupanta.

W dniu 1 września 1939 roku prezydent Rzeczypospolitej wydał dekret o rozciągnięciu mocy obowiązującej dekretu w przedmiocie przymusowego zarządu państwowego na obszar całego państwa ${ }^{4}$, co miało ułatwić utrzymanie niezbędnej produkcji, a tym samym zaopatrzenie w stanie wojny. Przepisy dekretu

2 Dz.U. z 1946 r. Nr 3, poz.17.

3 Por. T. Rabska, Prawo administracyjne stosunków gospodarczych, Poznań 1978, s. 13.

4 Dz.U. z 1939 r. Nr 87, poz. 545. 
z 16 grudnia 1918 roku w przedmiocie przymusowego zarządu państwowego ${ }^{5}$ w okresie po zakończeniu I wojny światowej i odzyskaniu niepodległości miały pozwolić w szczególności na objęcie przymusowym zarządem państwowym majątku zakładów i przedsiębiorstw przemysłowych, których utrzymanie w ruchu lub uruchomienie leżało w interesie państwa.

Działania wojenne oraz polityka okupanta spowodowały porzucanie majątku przez wielu obywateli państwa polskiego. Prowadzona przez okupanta polityka eksterminacji poskutkowała śmiercią wielu właścicieli przedsiębiorstw oraz ich rodzin. Część majątków z kolei pozostawiona została na skutek ucieczki właścicieli związanej z nadciągającymi wojskami radzieckimi.

Nowa władza zainteresowana była jak najszybszym uregulowaniem sytuacji prawnej oraz faktycznej opuszczonego i porzuconego mienia, zakładów mogących podjąć produkcję niezbędną na cele wojenne, a także mienia poniemieckiego w związku z przewidywanymi zmianami terytorialnymi. Szło bowiem o jak najszybsze ich formalne przejęcie i uruchomienie. Bezpośrednio po wojnie formułowano różne poglądy co do obowiązywania przedwojennych aktów prawnych, jednak dekret z dnia 16 grudnia 1918 roku w przedmiocie przymusowego zarządu państwowego został uznany za obowiązujący ${ }^{6}$, co pozwoliło na wykorzystanie jego przepisów w ramach dokonywanych powojennych przekształceń własnościowych jako podstawy do wydania licznych aktów stosowania prawa.

\section{Podstawy prawne decyzji nacjonalizacyjnych}

Podstawą prawną nacjonalizacji przemysłu w Polsce była ustawa z dnia 3 stycznia 1946 roku o przejęciu na własność państwa podstawowych gałęzi gospodarki narodowej ${ }^{7}$. Ustawa ta stała się podstawą do wydania licznych aktów wykonawczych. Działania podejmowane na jej podstawie miały pozwolić na realizację wskazanych ustawą celów, choć głównie szło o upaństwowienie przemysłu, czyli stworzenie bazy pod nowy system gospodarczy. Wszak nacjonalizacja, podobnie jak wywłaszczenie, jest postacią przekształceń własnościowych.

Ustawa z 3 stycznia 1946 roku zawierała przepisy pozwalające na przeprowadzenie nacjonalizacji w Polsce. $Z$ formalnego punktu widzenia był to treściowo bardzo skromny akt prawny liczący niewiele ponad dziesięć artykułów. Przesądzał on w treści art. 2 ust. 1 o przejściu na własność państwa - bez odszkodowania - przedsiębiorstw przemysłowych, górniczych, komunikacyjnych, bankowych, ubezpieczeniowych oraz handlowych Rzeszy Niemieckiej i byłego Wolnego Miasta Gdańska oraz ich obywateli. Wyjątki określone były w przepisie art. 2.

5 Dz.U. z 1918 r. Nr 21, poz. 67.

6 J. Litwin, W sprawie mocy obowiąującej niektórych ustaw przedwojennych, „Palestra” 1957, nr 3, s. 23-24.

7 Dz.U. z 1946 r. Nr 3, poz. 17 ze zm. 
Nacjonalizacja bez odszkodowania dotyczyła mienia poniemieckiego, które znajdowało się przede wszystkim na tak zwanych ziemiach odzyskanych i było przejmowane bezzwłocznie. Realizowana w odniesieniu do pozostałego mienia, prowadzona miała być za odszkodowaniem i została w istocie rozłożona w dłuższym czasie. Tym samym dokonano dywersyfikacji nacjonalizowanego mienia na dwie grupy: przedsiębiorstwa przejmowane bez odszkodowania i przedsiębiorstwa przejmowane za odszkodowaniem ${ }^{8}$, przy czym termin ,przedsiębiorstwo” używany był tutaj w znaczeniu podmiotowym. Tym samym pozostałe dokonywane działania nacjonalizacyjne odbywać się miały za odszkodowaniem. Zgodnie z przepisami art. 3 ustawy, w tym trybie państwo przejmowało na własność:

A. Przedsiębiorstwa górnicze i przemysłowe w podstawowych gałęziach gospodarki narodowej, bez względu na rozmiary i reprezentowane zdolności produkcyjne w 17 wymienionych w ustawie gałęziach gospodarki narodowej, a także przedsiębiorstwa komunikacyjne (kolei żelaznych normalnych i wąskotorowych, kolei elektrycznych, komunikacji powietrznej), przedsiębiorstwa telekomunikacyjne (telefoniczne, telegraficzne, radiowe).

B. Przedsiębiorstwa przemysłowe niewymienione w A, jeżeli zdolne są zatrudnić przy produkcji na jedną zmianę więcej niż 50 pracowników. Spod działania tego przepisu wyłącza się przedsiębiorstwa robót budowlanych oraz instalacyjnych bez względu na liczbę pracowników, którą zdolne są zatrudnić.

Przedsiębiorstwa przejęte na zasadzie przepisu art. 2 lub art. 3 przechodziły na rzecz państwa lub polskich osób prawnych prawa publicznego w całości wraz $\mathrm{z}$ nieruchomym i ruchomym majątkiem oraz wszelkimi prawami (prawo do firmy, patenty, licencje, znaki towarowe, użytkowe itp.). Przejęcie miało więc charakter pierwotny ${ }^{9}$, czyli obejmujący wszystkie składniki przedsiębiorstwa, wolne jednak od obciążeń i zobowiązań z wyjątkiem zobowiązań o charakterze publiczno-prawnym, zobowiązań na rzecz polskich osób prawnych prawa publicznego, zobowiązań na rzecz osób prawnych, stanowiących własność polskich osób prawnych prawa publicznego, służebności gruntowych oraz zobowiązań, mających swe źródło w stosunku najmu pracy lub odpowiedzialności za czyny niedozwolone.

Zgodnie $\mathrm{z}$ art. 3 za mienie przejęte przez państwo jego właściciel miał otrzymać odszkodowanie. Zasady obliczania odszkodowania, sposób jego wypłacania oraz tryb amortyzacji papierów wartościowych określić miało rozporządzenie Rady Ministrów, które wszakże nie zostało wydane, co formalnie uniemożliwiło wypłatę tych odszkodowań, choć nie całkowicie ${ }^{10}$.

${ }^{8}$ Por. T. Bigo, Ogólne podstawy prawne administracji stosunków gospodarczych, [w:] Prawo administracyjne, red. M. Jaroszyński, Warszawa 1952, s. 11.

${ }^{9}$ Por. Z. Rybicki, Administracja gospodarcza w PRL, Warszawa 1973, s. 248.

10 Sprawa wyglądała inaczej w przypadku wypłaty odszkodowań za nacjonalizację mienia cudzoziemców. Najogólniej mówiąc, odszkodowanie to wypłacone zastało na podstawie i w trybie określonym w zawartych przez Polskę umowach indemnizacyjnych z państwami, których obywa- 


\section{Decyzje nacjonalizacyjne}

O przejściu przedsiębiorstwa na własność państwa lub polskich osób prawnych prawa publicznego orzekał właściwy (ze względu na rodzaj przedsiębiorstwa) minister, którego orzeczenie było ostateczne i nie podlegało zaskarżeniu do Najwyższego Trybunału Administracyjnego. Orzeczenia w sprawach przejścia przedsiębiorstwa na własność państwa mogło być wydane trybie art. 3 ustawy jedynie do dnia 31 grudnia 1946 roku.

Decyzje dotyczące nacjonalizacji przedsiębiorstw wymienionych w art. 2 ustawy i przedsiębiorstw nacjonalizowanych za odszkodowaniem, ale należących do tak zwanych podstawowych gałęzi gospodarki narodowej, miały charakter decyzji określanych mianem deklaratoryjnych, czyli wskazujących na stopień zdeterminowania aktu administracyjnego przez podstawę prawą, taki, że norma prawna zawarta $\mathrm{w}$ ustawie determinuje te skutki w sposób niemal całkowity. Akt ten jedynie więc potwierdza skutki, które wynikają wprost z ustawy. Skutek prawny nie wynika $\mathrm{z}$ aktu deklaratoryjnego, lecz z samej ustawy. To przepis art. 2 ust. 1 przesądzał o przejściu przedsiębiorstw na własność państwa bez odszkodowania. Nie przewidywał on żadnych okoliczności i warunków niezbędnych do takiego przejścia. Ze skutkiem prawnym w postaci nabycia własności przez państwo mamy tu do czynienia w momencie wejścia w życie przepisów ustawy. Skutek prawny nie wynika więc $\mathrm{z}$ aktu administracyjnego deklaratoryjnego, który jedynie potwierdza ten fakt ${ }^{11}$. Stąd też akt ten obowiązuje ex tunc, czyli od momentu wejścia w życie zawartej w przepisie art. 2 normy ustawowej. Od tego momentu do chwili wydania aktu skutki prawne już istnieją, lecz są w pewien sposób „zawieszone” do jego formalnego wydania. Potwierdza on, że stosunek prawny już zaistniał ${ }^{12}$.

Przepisy art. 3 pkt B ustawy zawierają normy prawne, które były podstawą do wydania aktu administracyjnego konstytutywnego, oznaczającego, że z mocy tego właśnie orzeczenia ministra określone w nim przedsiębiorstwo przemysłowe zostało przejęte na własność przez państwo za odszkodowaniem. Norma ustawowa determinuje te decyzje inaczej niż w przypadku aktów deklaratoryjnych. Ustala ona jedynie możliwość własnej konkretyzacji i wyznaczenia własnych skutków w drodze takiego właśnie aktu, $\mathrm{Z}$ tego powodu akty te obowiązują ex nunc (od teraz), czyli od wydania aktu w ostatecznej formie ${ }^{13}$.

Kryterium związania indywidualnego aktu administracyjnego normą (podstawą prawną) staje się kanwą dalszego podziału decyzji na akty związane i akty swobodne. Podstawa prawna aktu administracyjnego może być tak skonstruowana

tele utracili swe mienie w wyniku nacjonalizacji. Szerzej zob. W. Dudek, Międzynarodowe aspekty nacjonalizacji w Polsce, Warszawa 1976.

11 Por. M. Zimmermann, [w:] M. Jaroszyński, M. Zimmermann, W. Brzeziński, Polskie prawo administracyjne, Warszawa 1956, s. 330.

12 Por. E. Ochendowski, Prawo administracyjne, część ogólna, Torun 2000, s. 168.

13 Por. J. Zimmermann, Prawo administracyjne, Kraków 2005, s. 349. 
(sformułowana), że w razie zaistnienia danego stanu faktycznego nie pozostawia organowi administracyjnemu żadnego wyboru działania (akt związany) lub sformułowana elastycznie, żeby organ wydający akt mógł wybrać rozwiązanie optymalne w danej bieżącej sytuacji faktycznej (akt swobodny). Aktami związanymi są zwłaszcza akty deklaratoryjne, natomiast konstytutywne cechują się pewną możliwością swobody, którą dysponuje organ wydający je. Należy wszakże wskazać, że stopień związania organu wydającego akt administracyjny przepisami prawa może być bardzo różny ${ }^{14}$.

Wskazuje się więc, że wśród norm ustawowych będących podstawą prawną wydania aktu administracyjnego wyróżnić można dwie kategorie:

1. normy, które precyzują wymogi ustawowe (warunki) działania organów administracyjnych i nakreślają w sposób jednoznaczny treść działania administracyjnego;

2. normy blankietowe, które nie oznaczają w sposób jednoznaczny treści działania administracyjnego, lecz zawierają tylko upoważnienie dla władzy administracyjnej do działania.

Normy blankietowe nie określają więc warunków działań, wskutek czego organ administracyjny ma wybór między różnymi sposobami zachowania się ${ }^{15}$. Niekiedy norma blankietowa może przybierać postać tak zwanej normy uznaniowej, zawierającej mniej lub bardzie precyzyjne zwroty niedookreślone, tworzącej przy ich interpretacji przez organ tak zwane luzy decyzyjne lub interpretacyjne. W takiej sytuacji swobodne uznanie dotyczy przyszłych skutków. Przedmiotem jego nie jest bowiem ustalenie znaczenia samego tekstu prawnego będącego podstawą ani ocena występujących faktów, lecz przede wszystkim określenie następującego skutku prawnego ${ }^{16}$.

$\mathrm{Z}$ formalnego punktu widzenie granice swobody organu w przypadku uznania administracyjnego mógłby określić sąd. Formalnie sąd administracyjny mógłby w sytuacjach wątpliwych co najmniej zbadać, czy nie zostały przekroczone granice uznania i czy podjęte $\mathrm{w}$ takiej sytuacji rozwiązanie nie było zupełnie dowolne ${ }^{17}$. Sytuacja taka jest możliwa jedynie w przypadku, gdy podejmowane rozstrzygnięcia poddane zostały kontroli sądowej. W przypadku decyzji podejmowanych na podstawie przepisów ustawy z dnia 3 stycznia, sądowa kontrola podejmowanych rozstrzygnięć została wyłączona przepisami ustawy.

Można przyjąć, że wyłączenie sądowej kontroli decyzji podejmowanych w sprawach załatwianych decyzjami deklaratoryjnymi dotyczy w gruncie rzeczy legalności formalnej. Wszak akt jedynie ustala, że na podstawie przepisów ustawy z dnia 3 stycznia należące do Rzeszy Niemieckiej przedsiębiorstwo przemysłowe

14 Por. ibidem, s. 350.

15 Por. T. Bigo, Prawo administracyjne. Instytucje ogólne, Wrocław 1948, s. 65.

16 Por. M. Mincer, Uznanie administracyjne, Torun 1983.

17 Por. T. Bigo, Kontrola uznania administracyjnego, ,Sprawozdania Wrocławskiego Towarzystwa Naukowego" 1959, nr 14 A. 
$\mathrm{X}$ z dniem wejścia w życie przepisów ustawy bez odszkodowania przeszło na własność państwa. Stąd też przyjąć można, że ewentualny brak sądowej kontroli tych decyzji nie stanowił dla legalności podejmowanych działań większego problemu.

Nieco inaczej sprawa zdaje się wyglądać w przypadku wydawania decyzji na podstawie art. 3 ustawy z 3 stycznia, dotyczących przejęcia przez państwo na własność za odszkodowaniem przedsiębiorstw przemysłowych nie wymienionych w pkt A, jeżeli zdolne są zatrudnić przy produkcji na jedną zmianę więcej niż 50 pracowników. Zgodnie z przepisem ustawy o tym, czy dane przedsiębiorstwo przemysłowe przejmowane było przez państwo na własność za odszkodowaniem, orzekał właściwy ze względu na rodzaj przedsiębiorstwa minister, którego orzeczenie jest ostateczne i nie ulega zaskarżeniu do Najwyższego Trybunału Administracyjnego. W odróżnieniu od decyzji wydawanych na podstawie przepisów art. 2, orzeczenie to było decyzją administracyjną konstytutywną. To orzeczenie decydowało o skutku, jakim było przejęcie przedsiębiorstwa przemysłowego przez państwo na własność za odszkodowaniem. Norma prawna będąca podstawą wydania takiej decyzji mogła być zaliczona do kategorii norm blankietowych, żeby nie powiedzieć, że była ona normą kompetencyjną. Wydany akt był więc $\mathrm{w}$ istocie aktem swobodnym.

Kanwą podjęcia orzeczenia, czyli warunkiem kwalifikacyjnym było zawarte w normie określenie ,jeżeli zdolne są zatrudnić przy produkcji na jedną zmianę więcej niż 50 pracowników". Przepis ten nie zawierał w swej treści żadnych innych warunków, które powinien brać pod uwagę organ wydający decyzję. Mieliśmy więc do czynienia z normą blankietową, której interpretacja zależała od podejścia organu. Wszakże organy podejmując decyzje nacjonalizacyjne same ustalały i oceniały stany faktyczne określone w normach blankietowych. I tak to one wykorzystywały przepis art. 6 ustawy dotyczący składników majątkowych włączonych w skład przedsiębiorstwa. Organy często uznawały, że nacjonalizacja może dotyczyć nie tylko samego przejmowanego na własność państwa przedsiębiorstwa, ale także innych składników majątkowych, które nie wchodziły w jego skład. Niejednokrotnie dotyczyło to przejęcia całego majątku właściciela nacjonalizowanego zakładu.

$\mathrm{Z}$ podobną sytuacją mieliśmy do czynienie w przypadku zakwalifikowania przedsiębiorstwa do znacjonalizowanych kategorii ze względu na liczbę pracowników zatrudnionych na jedną zmianę, bowiem nacjonalizacji według art. 3 ust. 1 lit. b) ustawy podlegały przedsiębiorstwa przemysłowe niewymienione w A, jeżeli zdolne są zatrudnić przy produkcji na jedną zmianę więcej niż 50 pracowników. Ten przepis wprowadzał niemal pełną dowolność w ustalaniu stanu faktycznego będącego podstawą kwalifikacji do wydania orzeczenia (formalnie, o czym zdawano się zapominać, dotyczyło to jedynie pracowników produkcyjnych, nie zaś wszystkich zatrudnionych). Dodatkowo także orzeczenia zapadały często w oparciu o hipotetyczna liczbę pracowników, która mogła być zatrudniona w przedsiębiorstwie, a nie liczbę rzeczywistą. Ustalano też niekiedy liczbę osób, które dane 
przedsiębiorstwo mogłoby zatrudniać w przyszłości, bądź też liczbę faktycznie zatrudnionych pracowników $\mathrm{w}$ dniu wejścia $\mathrm{w}$ życie ustawy, pomimo że przedsiębiorstwo było zdolne zatrudnić zupełnie inną liczbę pracowników w tym dniu. Te wszystkie elementy podnoszone były w orzeczeniach sądowych w sytuacji, gdy podejmowane orzeczenia nacjonalizacyjne mogły zostać poddane sadowej kontroli ${ }^{18}$ (ustawa nacjonalizacyjna sytuacji takiej nie przewidywała) w tak zwanych postępowaniach nieważnościowych.

Ustawa nie przewidywała w zasadzie żadnej procedury dotyczącej podejmowania orzeczeń. Określone wskazówki co do procedury postępowania w przypadku wydawania orzeczeń nacjonalizacyjnych wprowadzały przepisy rozporządzeniu Rady Ministrów z dnia 11 kwietnia 1946 roku w sprawie trybu postępowania przy przejmowaniu przedsiębiorstw na własność państwa ${ }^{19}$, zastąpione wkrótce przepisami rozporządzenia Rady Ministrów z dnia 30 stycznia 1947 roku w sprawie trybu postępowania przy przejmowaniu przedsiębiorstw na własność państwa ${ }^{20}$. Nie miało to wszakże większego wpływu na prawidłowość podejmowanych orzeczeń.

Warto też wskazać, że pominięto także problematykę odszkodowania, gdyż zgodnie z przepisem art. 7 ust. 1 ustawy 1 za przedsiębiorstwo przejęte przez państwo na własność (art. 3) jego właściciel miał otrzymać od Skarbu Państwa odszkodowanie. Odszkodowania te w stosunku do obywateli polskich nie zostały wypłacone. Radykalne rozwiązanie dotyczyło także mienia przejętego pod zarząd państwowy. Ustawa z dnia 25 lutego 1958 roku o uregulowaniu stanu prawnego mienia pozostającego pod zarządem państwowym ${ }^{21}$ uchyliła dekret $\mathrm{z}$ dnia 16 grudnia 1918 roku i stanowiła, że przedsiębiorstwa pozostające pod przymusowym zarządem przechodzą z mocy prawa na własność państwa bez odszkodowania.

\section{Zakończenie}

Decyzje podejmowane $\mathrm{w}$ procesie prywatyzacji w większości wypadków były orzeczeniami podejmowanym z wyraźnym naruszeniem prawa. Wskazuje na to wiele postępowań, jakie toczyły się i toczą przed sądami w sprawie unieważnienia tak zwanych decyzji nacjonalizacyjnych. Wydający te decyzje nie starali się przestrzegać nawet minimalnie określonych warunków określonych w normie ustawowej ograniczających $\mathrm{w}$ niewielkim stopniu swobodę organu $\mathrm{w}$ procesie jej wydawania. Korzystali więc z możliwości podejmowania decyzji w sposób

18 Zob. na przykład wyrok Wojewódzkiego Sądu Administracyjnego w Poznaniu z 4 lutego 2004 roku, sygn. akt II SA/Po 3076/01); wyrok Wojewódzkiego Sądu Administracyjnego w Warszawie z 2 lutego 2000 roku, sygn. akt IV SA 1495/99; oraz wyrok Naczelnego Sądu Administracyjnego z dnia 21 marca 2018 roku, I OSK 1409/16.

19 Dz.U. z 1946 r. Nr 17, poz. 114.

20 Dz.U. z 1947 r. Nr 16, poz. 62.

21 Dz.U. z 1958 r. Nr 11, poz. 37. 
dyskrecjonalny, czyli swobodny, nieskrępowany konkretnymi przepisami prawa, nawet tymi zawartymi w ustawie.

Można wskazać, że autorytaryzm w działaniach podejmowanych w procesie nacjonalizacji wyrażał się w dużym stopniu brakiem troski o proceduralne legitymizowanie pojmowanych władczych rozstrzygnięć, w większości niekorzystnych dla ich adresatów ${ }^{22}$. Podmioty władzy autorytarnej kontentują się samym założonym skutkiem jaki ma być osiągnięty za pomocą tych rozstrzygnięć. Dominował cel, procedury prawne jego osiągania stawały się w tej sytuacji mało istotne. Świadczyło o tym także niedotrzymanie zapowiedzi wypłaty odszkodowania, co spowodowało, że wbrew ustawie przedsiębiorstwa stanowiące własność obywateli polskich przechodziły na własność państwa bez odszkodowania.

\section{Bibliografia}

Bigo T., Prawo administracyjne. Instytucje ogólne, Wrocław 1948.

Bigo T., Ogólne podstawy prawne administracji stosunków gospodarczych, [w:] Prawo administracyjne, red. M. Jaroszyński, Warszawa 1952.

Bigo T., Kontrola uznania administracyjnego, „Sprawozdania Wrocławskiego Towarzystwa Naukowego" 1959, nr 14 A.

Dudek W., Międzynarodowe aspekty nacjonalizacji w Polsce, Warszawa 1976.

Grabski S., Upaństwowienie czy uspołecznienie i unarodowienie, „Ekonomista Polski” 1942, nr 4.

Litwin S., W sprawie mocy obowiązujacej niektórych ustaw przedwojennych, „Palestra” 1957, nr 3.

Mincer M., Uznanie administracyjne, Toruń 1983.

Ochendowski E., Prawo administracyjne, część ogólna, Torun 2000.

Rabska T., Prawo administracyjne stosunków gospodarczych, Poznań 1978.

Rybicki Z., Administracja gospodarcza w PRL, Warszawa 1973.

Tokarczyk R., Autorytaryzm — dociekanie istoty pojęcia, „Historia i Polityka” 2009-2010, nr 2-3 (9-10).

Zimmermann M., [w:] M. Jaroszyński, M. Zimmermann, W. Brzeziński, Polskie prawo administracyjne, Warszawa 1956.

Zimmermann J., Prawo administracyjne, Kraków 2005.

22 Por. R. Tokarczyk, Autorytaryzm - dociekanie istoty pojęcia, „Historia i Polityka” 20092010, nr 2-3 (9-10), s. 37. 